\title{
DAPATKAH PROGRAM HOME VISIT LAKTASI PADA 4 MINGGU PERTAMA MENINGKATKAN PRAKTIK MENYUSUI?
}

\author{
Oswati Hasanah ${ }^{1}$, Riri Novayelinda ${ }^{2}$ \\ ${ }^{1,2}$ Fakultas Keperawatan Universitas Riau \\ Fakultas Keperawatan Universitas Riau Jalan Pattimura No 9 \\ Gedung G Pekanbaru Riau Kode Pos 28131 Indonesia \\ Email: unni_08@yahoo.com
}

\begin{abstract}
Abstrak
Tujuan dari penelitian ini adalah untuk mengidentifikasi pengaruh intervensi pemberian makan bayi selama 3 minggu. Penelitian dilakukan di Pekanbaru. Penelitian ini menggunakan metode quasy eksperimen dengan desain pre dan post test. Sampel adalah 40 ibu yang melahirkan di klinik bidan yang dibagi secara acak menjadi dua kelompok yaitu kelompok intervensi dan kelompok kontrol. Kelompok intervensi menerima informasi pendidikan kesehatan selama mereka dirawat di klinik. Lampiran perlekatan dinilai dengan menggunakan skor LATCH dan diukur sebelum dan sesudah intervensi untuk kedua kelompok. Kelompok intervensi menerima dua kali program kunjungan rumah dan satu kali program tindak lanjut selama 3 minggu pertama. Program intervensi dilakukan berdasarkan modul yang telah dikembangkan oleh peneliti. Program intervensi dilakukan oleh 2 petugas kesehatan yang direkrut untuk penelitian ini dan selama intervensi mereka hanya di bolehkan mengikuti langkah dalam modul menyusui. Studi ini dengan menggunakan T dependen menunjukkan bahwa setelah 4 minggu LATCH skor bayi pada kelompok intervensi lebih tinggi dibandingkan dengan LATCH skor bayi pada kelompok kontrol (p value $=0,00$ ). Studi ini juga menemukan bahwa praktik pemberian ASI eksklusif juga lebih tinggi pada kelompok intervensi daripada kelompok kontrol. Studi ini juga merekomendasikan untuk menilai pengaruh program ini terhadap praktik pemberian makan setelah 4 dan 6 bulan
\end{abstract}

Kata kunci: ASI eksklusif, LATCH skor, kunjungan rumah, program laktasi

\begin{abstract}
s
The aim of this study is to identify the effect of 3 weeks intervention into infant feeding practice. The study was conducted in Pekanbaru. This study used the quasy experiment method with pre and post test design . The sample were 40 mothers who gave birth at midwifery those were assigned randomly into two groups : the intervention group and the control group received breastfeeding education information during their time in the clinic. The infant's breast attachment were scored using LATCH score and were measured before and after intervention for both groups. The intervention groups received two times home visit program and one time follow up program during the first 3 weeks. The intervention program were conducted based on breatfeeding support module that has been developed by researcher. The intervention program were conducted by 2 health care workers who were recruited for this study. During the intervention program they only follow the step in the breastfeeding module. This study with t-test (dependent and independent t-test) found that after 4 weeks the LATCH score of the babies in the intervention group is higher compare to the LATCH score of the babies in the control group ( $p$ value=0.00). This study also found that the exclusive breastfeeding practice is also higher in the intervention group than control group. This study also recommends to assess the effect of this program into the feeding practice after 4 and 6 months
\end{abstract}

Keywords : exclusive breastfeeding home visit, lactation program, LATC H score 
Oswati Hasanah, Riri Novayelinda, Dapatkah Program Home Visit Laktasi pada 4 Minggu Pertama meningkatkan Praktik Menyusui?

\section{PENDAHULUAN}

Air Susu Ibu (ASI) eksklusif adalah pemberian ASI saja pada bayi tanpa pemberian makanan tambahan lain, termasuk air putih dan madu (WHO, 2009). Sejak tahun 2006 WHO merekomendasikan untuk memberikan ASI secara eksklusif hingga bayi berusia 6 bulan pertama kehidupannya. Pemerintah Indonesia saat ini juga sudah menganjurkan untuk pemberian ASI eksklusif selama 6 bulan ini. Hal ini bertujuan agar bayi dapat mencapai pertumbuhan dan perkembangan yang optimal ditahun pertama kehidupannya. Keseriusan pemerintah dituangkan dalam peraturan pemerintah yaitu Peraturan Pemerintah Republik Indonesia No. 33 Tahun 2012 Pasal 1 Ayat 2.

ASI merupakan nutrisi terbaik bagi neonatus. Penelitian pada bayi dengan berat badan lahir rendah (BBLR) menunjukkan bahwa terdapat perbedaan berat badan yang signifikan pada bayi BBLR yang di berikan ASI pada 2 minggu pertama dengan bayi BBLR yang di berikan susu formula (Susanti, Hasanah \& Utami, 2014). Systematic review menyimpulkan bahwa pemberian ASI secara eksklusif pada 6 bulan pertama kehidupan dapat mengurangi angka kesakitan bayi akibat infeksi gastrointestinal baik di negara maju maupun di negara berkembang (Kramer \& Kakuma, 2012).

Secara global, hanya $36 \%$ bayi usia 0-6 bulan yang diberi ASI ekslusif (WHO, 2015). Angka ini menurun dari tahun 2014 yaitu sebanyak 38\% (WHO, 2014). Hasil survei demografi dan kesehatan Indonesia menunjukkan cakupan pemberian ASI ekslusif pada bayi 0-6 bulan berfluktuasi sementara penggunaan susu botol semakin meningkat dari tahun 2002-2012 (Kemenkes RI, 2014). Di Indonesia, persentase menyusui eksklusif selama 6 bulan pertama pada tahun 2013 hanya sekitar 54,3\% (Riskesdas, 2013). Angka ini belum mencapai target yang ditetapkan pada tahun 2013 yaitu $75 \%$ (Kemenkes RI, 2014). Persentase menyusui ekslusif semakin menurun dengan meningkatnya kelompok umur bayi. Data yang dipaparkan oleh Riskesdas tahun 2013, didapatkan bahwa persentase pemberian ASI saja dalam 24 jam terakhir menurun seiring meningkatnya umur bayi dengan persentase terendah pada anak umur 6 bulan $(30,2 \%)$. Sebanyak 42,7\% ibu di kota Pekanbaru mulai menyusui < 1 jam, tertinggi di siak $(65,1 \%)$ dan terendah di Pelalawan $(15,7 \%)$. Persentase ibu yang memberikan semua kolostrum pada bayi tertinggi di Siak (100\%), terendah di Rokan Hulu (47,2 \%) dan di Pekanbaru cukup tinggi yaitu sebanyak 92,7\%. Persentase anak usia 0-23 bulan yang masih disusui tertinggi di Kuantan Singingi $(88,1 \%)$, sementara kota Pekanbaru menempati urutan terendah yaitu 68,3\% (Riskesdas, 2013).

Hasil studi pendahuluan yang dilakukan di RSUD Arifin Achmad Pekanbaru dan Puskesmas Rumbai terhadap 38 ibu-ibu yang pernah menyusui, ditemukan bahwa ibu telah 
memberikan susu formula dan makanan tambahan pada bayi sebelum usia 6 bulan. Alasan yang mendasari hal tersebut adalah ibu kurang memahami tentang ASI eksklusif (24\%), merasa bahwa ASI mereka sedikit (34\%), bayi tidak mau menyusu (9\%), anjuran keluarga (7\%), masalah payudara $(8 \%)$ dan anjuran teman (4\%), dan bekerja (10\%).

Rendahnya praktik pemberian ASI eksklusif ini diduga karena banyak faktor, antara lain ibu tidak tahu cara memberikan ASI, ibu tahu tentang ASI eksklusif tetapi tidak mau melakukan, serta gencarnya promosi makanan pendamping ASI sebelum bayi berusia 5 bulan. Tingkat pengetahuan ibu merupakan salah satu faktor terkait dengan pemberian ASI. Penelitian yang dilakukan di Kecamatan Sidomulyo Pekanbaru menunjukkan bahwa ibu yang memiliki pengetahuan kurang dan cenderung untuk memberikan makanan tambahan lebih dini (Kumalasari, Sabrian \& Hasanah, 2015). Hal ini tentu akan memiliki pengaruh durasi pemberian ASI eksklusif.

Faktor lain yang menyebabkan kegagalan ASI eksklusif adalah bayi tidak mau atau sulit menyusu.Teknik menyusui merupakan salah satu aspek yang dihubungkan dengan proses menyusui. Penelitian yang dilakukan Kronbrog dan Vaeth (2009) dengan jumlah populasi 570 ibu didapatkan hasil $61 \%$ ibu mempunyai masalah dalam posisi menyusui dan $52 \%$ ibu mempunyai perlekatan yang tidak tepat. Penelitian lain juga dilakukan oleh Pertiwi, Solehati dan Widiasih (2012) tentang faktor-faktor yang mempengaruhi proses laktasi ibu dengan bayi usia 0-6 bulan di Desa Cibeusi Kecamatan Jatinangor dengan sampel 49 orang dan didapatkan hasil bahwa $55 \%$ ibu gagal dalam pemberian ASI karena teknik menyusui yang kurang baik.

Alasan lain penyebab pendeknya durasi pemberian ASI adalah produksi ASI yang sedikit. Produksi dan pengeluaran ASI didukung oleh posisi dan perlekatan bayi yang baik saat pemberian ASI. Hai ini akan mencegah terjadinya masalah menyusui seperti bendungan pada payudara, lecet pada puting susu dan mastitis. Informasi tentang posisi dan perlekatan yang baik saat menyusui kurang di berikan pada saat pemberian informasi tentang proses menyusui. Berdasarkan penelitian di temukan bahwa $43 \%$ bayi mengalami masalah menyusui dan hampir sebagian besar tidak menunjukkan posisi dan perlekatan yang baik saat menyusui bayi. Informasi tentang pemberian posisi dan perlekatan yang di berikan pada minggu pertama terbukti memberikan pengaruh terhadap perbaikan posisi menyusui dan perlekatan bayi (Thakre, Thakre, Ughade, Golawar, Thakre \& Priya 2012).

Teknik perlekatan sangat perlu diajarkan sejak awal kelahiran untuk mencegah permasalahan dalam pemberian ASI dihari postpartum berikutnya. Hal ini sesuai dengan penelitian yang dilakukan oleh I Mannan dkk (2008) tentang can early postpartum home 
Oswati Hasanah, Riri Novayelinda, Dapatkah Program Home Visit Laktasi pada 4 Minggu Pertama meningkatkan Praktik Menyusui?

visits by trained community health workers improve breastfeeding of newborn. Hasil penelitian menunjukkan12-15\% dari 486.351 responden ditemukan masalah tentang teknik perlekatan dan posisi menyusui, ibu postpartum yang mendapat kunjungan rumah tentang teknik perlekatan dan posisi menyusui selama tiga kali dalam minggu pertama kelahiran hanya mengalami permasalahan pemberian ASI sebanyak $6 \%$ dibandingkan ibu yang tidak mendapatkan kunjungan rumah (34\%). Hal ini menjelaskan bahwa perlu dilakukan intervensi tentang teknik perlekatan lebih awal kelahiran guna mencegah permasalahan dalam pemberian ASI sehingga dapat meningkatkan frekuensi pemberian ASI. Observasi dan perbaikan pada pada teknik menyusui yang dilakukan oleh tenaga terlatih akan mempertahankan kemampuan ibu dalam menyusui yang pada akhirnya mencegah terjadinya masalah dalam proses menyusui (Kronborg \& Vaeth, 2009).

Untuk meningkatkan angka pemberian ASI eksklusif perlu dukungan dari berbagai pihak salah satunya adalah petugas kesehatan. Petugas kesehatan merupakan salah unsur yang memberikan dampak positif dalam keberhasilan ASI eksklusif. Peran petugas kesehatan dalam menfasilitasi inisiasi menyusui dini, memberikan saran untuk pemberian ASI eksklusif, melakukan penilaian dan edukasi tentang teknik menyusui saat melakukan kunjungan rumah memberikan efek positif dalam keberhasilan pemberian ASI eksklusif (Sabati, 2015). Petugas kesehatan merupakan sosok yang di percaya oleh ibu sebagai sumber informasi utama. Informasi yang diberikan oleh petugas dianggap sebagai sumber yang reliable oleh ibu.

Edukasi tentang laktasi yang dilakukan di rumah sakit biasanya dilakukan dengan menggunakan media yang dapat meningkatkan pengetahuan, kemampuan dan motivasi ibu tentang menyusui (Lestari, Amelia, \& Rahmalia, 2012). Sayangnya edukasi tentang laktasi banyak dilakukan berbasis klinik, dimana ibu mendapatkan informasi tentang menyusui saat ibu berada di rumah sakit, pukesmas atau datang ke klinik laktasi.

Berdasarkan studi pendahuluan yang dilakukan di rumah sakit atau puskesmas, waktu yang di habiskan oleh petugas kesehatan untuk melakukan edukasi rata rata kurang dari 10 menit untuk edukasi perorangan dan 30 menit untuk edukasi kelompok (penyuluhan). Edukasi di lakukan oleh dokter, bidan, perawat di ruang rawat atau oleh kader kesehatan di posyandu. Kebanyakan edukasi dilakukan tidak bersifat berkelanjutan dan hanya didasarkan pada kebutuhan saat itu. Belum ditemukan adanya penelitian yang dilakukan di Pekanbaru tentang edukasi laktasi yang bersifat berkelanjutan dan dilakukan mulai dari ibu berada di rumah sakit diikuti dengan program follow up di rumah. 


\section{METODE}

Penelitian ini adalah quasi eksperiment dengan post test only control group design yaitu dapat mengukur manipulasi pada kelompok eksperimen dengan cara membandingkannya dengan kelompok kontrol. Pada penelitian ini kelompok intervensi menerima program dukungan laktasi yang meliputi edukasi di ruang rawat dan home visit. Sedangkan pada kelompok kontrol hanya menerima edukasi saat di rawat diruang rawat.

Penelitian ini dilakukan di dua klinik bidan di kota Pekanbaru dan di RSUD Petala Bumi. Populasi dalam penelitian ini adalah seluruh ibu postpartum primipara Berdasarkan studi pendahuluan, jumlah primipara adalah 66 orang selama 2 bulan.

Pengambilan sampel pada penelitian ini menggunakan teknik non probability sampling dengan jenis purposive sampling, kriteria inklusi sebagai berikut: primipara, ibu postpartum hari pertama baik persalinan normal ataupun sectio seccaria, bersedia menjadi reponden, bersedia dihubungi kembali sebagai responden untuk post test, bayi yang lahir tidak mengalami kelainan kongenital, bayi tidak mengalami permasalahan dalam persalinan, seperti terminum air ketuban, prematur dan berada pada inkubator, dan lainlain. Sampel yang diambil dalam penelitian ini adalah 40 orang responden.

Alat pengumpulan data adalah lembar kuesioner tentang data demografi dan lembar observasi tentang teknik perlekatan dan posisi menyusui, dan tanda -tanda kecukupan menyusui, berat badan bayi. Pada tahap postes peneliti juga menggunakan kurva BB/ U untuk menilai status berat badan bayi.

Responden penelitian ditemui pada hari pertama post partum. Lokasi pertemuan dengan responden adalah di ruang rawat yang kemudian di berikan edukasi tentang teknik dan cara menyusui. Intervensi akan dilakukan selama lebih kurang 30 menit yang dilakukan oleh 2 orang tenaga perawat yang sudah di latih sebelumnya. Program penyuluhan mengikuti tahapan konseling ASI. Aspek yang didiskusikan adalah posisi pemberian ASI, cara perlekatan bayi ke payudara ibu. Pada tahap ini pendidikan kesehatan dilakukan dengan menggunakan boneka dan alat peraga serta praktek langsung dengan bayi. Pada sesi ini perawat menggunakan ceklist untuk memastikan semua informasi diberikan. Pada tahap ini baik kelompok kontrol dan eksperimen sama sama menerima intervensi.

Pada hari ke-7 perawat melakukan kunjungan rumah kemudian untuk melakukan penilaian terhadap teknik perlekatan dan posisi menyusui. Perawat juga menilai tentang pola pemberian makanan bayi dan apakah masalah menyusui juga muncul. Pada tahap ini perawat melakukan edukasi tentang cara mengatasi masalah dalam menyusui dan menjelaskan tanda-tanda kecukupan ASI pada bayi. Pada tahapan ini perawat juga akan mengajarkan tentang cara untuk memerah ASI dengan 
Oswati Hasanah, Riri Novayelinda, Dapatkah Program Home Visit Laktasi pada 4 Minggu Pertama meningkatkan Praktik Menyusui?

menggunakan modul tentang manajemen laktasi pada ibu. Prosedur ini berlaku untuk kelompok intervensi.

Pada hari ke-14 edukasi dilakukan dengan menggunakan telepon dan mengidentifikasi masalah yang terjadi dan tipe pemberian makananan pada bayi. Perawat juga melakukan konseling lewat telepon. Prosedur ini berlaku untuk kelompok intervensi.

Pada hari ke-30 perawat melakukan pengkajian terhadap pola menyusui, masalah saat menyusui, tanda kecukupan bayi mendapatkan ASI. Pengkajian dilakukan dengan teknik observasi dan wawancara. Prosedur ini berlaku pada kelompok kontrol dan eksperimen.

Data pada penelitian dianalisis dengan menggunakan komputer dengan menggunakan uji $\mathrm{T}$ ( $\mathrm{T}$ dependent dan $\mathrm{T}$ Independen) dengan membandingkan nilai rata rata angka pada kedua kelompok.

\section{HASIL}

\section{Analisis Univariat}

Karakteristik responden dalam penelitian ini dilihat berdasarkan umur, pendidikan, pekerjaan dan jenis kelamin bayi. Dapat dilihat pada tabel 1

Tabel 1

Karakteristik responden

\begin{tabular}{lcccccc}
\hline \multirow{2}{*}{ Karakteristik } & $\begin{array}{c}\text { Eksperimen } \\
(\mathbf{n = 2 0})\end{array}$ & \multicolumn{2}{c}{$\begin{array}{c}\text { Kontrol } \\
(\mathbf{n = 2 0})\end{array}$} & $\begin{array}{c}\text { Jumlah } \\
(\mathbf{n = 4 0})\end{array}$ \\
\cline { 2 - 7 } & $\mathbf{n}$ & $\mathbf{\%}$ & $\mathbf{n}$ & $\mathbf{\%}$ & $\mathbf{n}$ & $\mathbf{\%}$ \\
\hline Umur Ibu & & & & & & \\
a. 20-40 tahun & $\mathbf{2 0}$ & $\mathbf{1 0 0}$ & $\mathbf{1 9}$ & $\mathbf{9 0}$ & $\mathbf{3 9}$ & $\mathbf{9 7 , 5}$ \\
b. $>40$ tahun & $\mathbf{0}$ & $\mathbf{0}$ & $\mathbf{1}$ & $\mathbf{1 0}$ & $\mathbf{1}$ & $\mathbf{2 , 5}$ \\
\hline Total & $\mathbf{2 0}$ & $\mathbf{1 0 0}$ & $\mathbf{2 0}$ & $\mathbf{1 0 0}$ & $\mathbf{4 0}$ & $\mathbf{1 0 0}$ \\
\hline Pendidikan Ibu & & & & & & \\
a. SD & $\mathbf{0}$ & $\mathbf{0}$ & $\mathbf{1}$ & $\mathbf{5}$ & $\mathbf{1}$ & $\mathbf{2 , 5}$ \\
b. SMP & $\mathbf{1}$ & $\mathbf{5}$ & $\mathbf{6}$ & $\mathbf{3 0}$ & $\mathbf{7}$ & $\mathbf{1 7 , 5}$ \\
c. SMA & $\mathbf{1 2}$ & $\mathbf{6 0}$ & $\mathbf{1 1}$ & $\mathbf{5 5}$ & $\mathbf{2 3}$ & $\mathbf{5 7 , 5}$ \\
d. PT & $\mathbf{7}$ & $\mathbf{3 5}$ & $\mathbf{2}$ & $\mathbf{1 0}$ & $\mathbf{9}$ & $\mathbf{2 2 , 5}$ \\
\hline Total & $\mathbf{2 0}$ & $\mathbf{1 0 0}$ & $\mathbf{2 0}$ & $\mathbf{1 0 0}$ & $\mathbf{4 0}$ & $\mathbf{1 0 0}$ \\
\hline Pekerjaan Ibu & & & & & & \\
a. Bekerja & $\mathbf{3}$ & $\mathbf{1 5}$ & $\mathbf{1}$ & $\mathbf{5}$ & $\mathbf{4}$ & $\mathbf{1 0}$ \\
b. Tidak & $\mathbf{1 7}$ & $\mathbf{8 5}$ & $\mathbf{1 9}$ & $\mathbf{9 5}$ & $\mathbf{3 6}$ & $\mathbf{9 0}$ \\
$\quad$ bekerja & & & & & & \\
\hline Total & $\mathbf{2 0}$ & $\mathbf{1 0 0}$ & $\mathbf{2 0}$ & $\mathbf{1 0 0}$ & $\mathbf{4 0}$ & $\mathbf{1 0 0}$ \\
\hline Jenis Kelamin & & & & & & \\
Bayi & & & & & & $\mathbf{8 0}$ \\
c. Laki-Laki & $\mathbf{1 7}$ & $\mathbf{8 5}$ & $\mathbf{1 5}$ & $\mathbf{7 5}$ & $\mathbf{3 2}$ & $\mathbf{2 0}$ \\
d. Perempuan & $\mathbf{3}$ & $\mathbf{1 5}$ & $\mathbf{5}$ & $\mathbf{2 5}$ & $\mathbf{8}$ & \\
\hline & & & & & & \\
\hline
\end{tabular}


Jurnal Ners Indonesia, Vol.10 No.1, September 2019

\begin{tabular}{lllllll}
\hline Total & 20 & 100 & 20 & 100 & 40 & 100
\end{tabular}

Data pada tabel 1 menunjukkan bahwa hampir keseluruhan ibu berusia $<40$ tahun (97.5\%), sebagian besar dengan latar belakang pendidikan SMA (57.5\%), hampir semua ibu tidak bekerja $(90 \%)$ dan sebagian besar memiliki bayi dengan jenis kelamin laki-laki $(80 \%)$.

\section{Analisis Bivariat}

a. Berat Badan Bayi

Tabel 2

Perbedaan berat badan kunjungan keempat pada kelompok kontrol dan eksperimen

\begin{tabular}{lcc}
\hline BB Bayi & Mean & p value \\
\hline Kelompok Kontrol & 3905,00 & \multirow{2}{*}{0,026} \\
Kelompok Eksperimen & 4230,00 & \\
\hline
\end{tabular}

Tabel 3

Perbedaan berat badan lahir bayi dan berat badan kunjungan keempat pada kelompok kontrol dan eksperimen

\begin{tabular}{llccc}
\hline Kelompok & BB Bayi & Mean & SD & p value \\
\hline $\begin{array}{l}\text { Kelompok } \\
\text { kontrol }\end{array}$ & BBL & $\mathbf{3 0 7 5 , 0 0}$ & $\mathbf{3 5 5 , 2 2 4}$ & $\mathbf{0 , 0 0 0}$ \\
& $\begin{array}{l}\text { BB kunjungan } \\
\text { keempat }\end{array}$ & $\mathbf{3 9 0 5 , 0 0}$ & $\mathbf{3 4 8 , 6 4 4}$ & \\
\hline $\begin{array}{l}\text { Kelompok } \\
\text { eksperimen }\end{array}$ & BBL & $\mathbf{3 1 9 0 , 0 0}$ & $\mathbf{3 5 2 , 2 8 6}$ & $\mathbf{0 , 0 0 0}$ \\
& $\begin{array}{l}\text { BB kunjungan } \\
\text { keempat }\end{array}$ & $\mathbf{4 2 3 0 , 0 0}$ & $\mathbf{4 8 6 , 7 7 2}$ & \\
\hline
\end{tabular}

Berdasarkan tabel 2 dengan menggunakan uji $\mathrm{T}$ independent dapat terlihat adanya perbedaan berat badan bayi post test antara kelompok eksperimen dan kelompok kontrol, perbedaan berat badan antara kedua kelompok ini cukup signifikan dengan dengan $\mathrm{p}$ value $=0,000$ ( $\mathrm{p}$ value $<\alpha$ ). Berdasarkan

\section{b. Skor Perlekatan (latch score)}

Tabel 4.

Perbedaan skor perlekatan pada kelompok kontrol dan eksperimen (post test)

\begin{tabular}{lcc}
\hline Skor Perlekatan & Mean & $p$ value \\
\hline Kelompok Kontrol & 0,95 & 0,000 \\
\end{tabular}

perbandingan berat badan lahir dan berat badan pada post test, dapat terlihat pada kedua kelompok, sama-sama terjadi peningkatan berat badan bayi. Dari hasil analisis lebih lanjut terlihat ada perbedaan yang signifikan antara berat badan lahir dan berat badan bayi saat kunjungan ke empat (post test) (Tabel 3).

\section{Kelompok \\ Eksperimen}

2,60

Tabel 4 menunjukkan bahwa skor perlekatan pada kunjungan ke empat pada kedua kelompok terbukti berbeda secara 
Oswati Hasanah, Riri Novayelinda, Dapatkah Program Home Visit Laktasi pada 4 Minggu Pertama meningkatkan Praktik Menyusui?

signifikan dengan $\mathrm{p}$ value $=0,000$ ( $\mathrm{p}$ value

$<\alpha)$.

Tabel 5.

Perbedaan skor perlekatan sebelum dan sesudah kunjungan ke empat pada kelompok kontrol dan eksperimen

\begin{tabular}{llccc}
\hline Kelompok & Skor Perlekatan & Mean & SD & p value \\
\hline $\begin{array}{l}\text { Kelompok } \\
\text { kontrol }\end{array}$ & Pre test & $\mathbf{0 , 8 0}$ & $\mathbf{0 , 6 9 6}$ & $\mathbf{0 , 0 8 3}$ \\
& Post test & $\mathbf{0 , 9 5}$ & $\mathbf{0 , 6 0 5}$ & \\
\hline $\begin{array}{l}\text { Kelompok } \\
\text { eksperimen }\end{array}$ & Pre test & $\mathbf{1 , 5 5}$ & $\mathbf{1 , 1 9 1}$ & $\mathbf{0 , 0 0 0}$ \\
& Post test & $\mathbf{2 , 6 0}$ & $\mathbf{0 , 9 9 5}$ & \\
\hline
\end{tabular}

Besarnya perbedan skor perlekatan pada kelompok eksperimen sebelum dan sesudah intervensi dapat terlihat pada tabel 5. Dimana skor perlekatan sebelum dan sesudah intervensi pada kelompok eksperimen juga berbeda secara signifikan dengan $\mathrm{p}$ value $=0,000$ ( $\mathrm{p}$ value $<\alpha$ ). Dibandingkan dengan skor perlekatan pada kelompok kontrol yang tidak mengalami perubahan yang bermakna.

\section{Frekuensi dan durasi menyusui}

Berdasarkan tabel 6 dan tabel 7 dibawah, tidak terlihat ada perbedaan yang signifikan antara frekuensi dan durasi menyusui pada kelompok kontrol dan eksperimen pada kunjungan yang keempat dengan $\mathrm{p}$ value $=0,000(\mathrm{p}$ value $<\alpha)$. Tetap terlihat adanya peningkatan, walaupun

\section{PEMBAHASAN}

Data pada tabel 1 menunjukkan bahwa hampir keseluruhan ibu berusia $<40$ tahun (97,5\%), sebagian besar dengan latar belakang pendidikan SMA $(57,5 \%)$, hampir semua ibu peningkatannya tidak cukup bermakna. Ini menunjukkan edukasi yang efektif dapat meningkatkan pemahaman ibu tentang posisi dan perlekatan yang tepat.

Tabel 6

Perbedaan frekuensi menyusui pada kelompok kontrol dan eksperimen pada kunjungan ke empat (post test)

\begin{tabular}{lccc}
\hline $\begin{array}{l}\text { Frekuensi } \\
\text { Menyusui }\end{array}$ & Mean & $\begin{array}{c}\text { Sum of } \\
\text { Ranks }\end{array}$ & $\begin{array}{c}\boldsymbol{p} \\
\text { value }\end{array}$ \\
\hline $\begin{array}{l}\text { kelompok } \\
\text { kontrol }\end{array}$ & 18,40 & 355,224 & \\
$\begin{array}{l}\text { Kelompok } \\
\text { Eksperimen }\end{array}$ & 22,60 & 348,644 & $\mathbf{0 , 2 6 5}$ \\
\hline
\end{tabular}

Tabel 7

Perbedaan durasi menyusui pada kelompok kontrol dan eksperimen (post test)

\begin{tabular}{lccc}
\hline $\begin{array}{l}\text { Durasi } \\
\text { Menyusui }\end{array}$ & Mean & $\begin{array}{c}\text { Sum of } \\
\text { Ranks }\end{array}$ & $\begin{array}{c}\boldsymbol{p} \\
\text { value }\end{array}$ \\
\hline $\begin{array}{l}\text { Kelompok } \\
\text { Kontrol }\end{array}$ & 23,33 & 466,50 & \\
$\begin{array}{l}\text { Kelompok } \\
\text { Eksperimen }\end{array}$ & 17,68 & 353,50 & $\mathbf{0 , 1 2 7}$ \\
\hline
\end{tabular}

tidak bekerja (90\%) dan sebagian besar memiliki bayi dengan jenis kelamin laki-laki (80\%). Karakteristik usia responden ikut dipengaruhi oleh kriteria pemilihan responden 
pada saat rekruitment responden, karena ibu yang dipilih adalah ibu primipara. Sedangkan karakteristik yang lain tidak ikut dipengaruhi oleh kriteria pemilihan responden.

Berdasarkan tabel 2 dapat terlihat adanya perbedaan berat badan bayi post test antara kelompok eksperimen dan kelompok kontrol, perbedaan berat badan antara kedua kelompok ini cukup signifikan dengan $\mathrm{p}$ value $=0,000(P$ value $<\alpha$ ). Berdasarkan tabel 3 dapat terlihat perbandingan berat badan lahir dan berat badan pada post test, dapat terlihat pada kedua kelompok, sama-sama terjadi peningkatan berat badan bayi. Dari hasil analisis lebih lanjut terlihat ada perbedaan yang signifikan antara berat badan lahir dan berat badan bayi saat kunjungan ke empat (post test). Secara teori, setelah melewati periode transisi pada minggu pertama kelahiran,maka bayi secara normal akan mengalami kenaikan berat badan sebanyak 500 gram sampai 800 gram selama 1 bulan pertama (Hockenberry \& Wilson, 2009). Terlihat kenaikan berat badan bayi pada kedua kelompok lebih dari rentang normal. Kenaikan ini dapat dimungkinkan karena anak sudah melewati proses adaptasi dan mendapat nutrisi yang cukup dari ASI. ASI terutama hind milk mengandung lemak yang banyak (Potts \& Mandleco, 2007). Jika bayi cukup mendapatkan hind milk setiap kali menyusu, maka bayi akan meningkat berat badannya secara signifikan pada 3 bulan pertama kehidupan.
Tabel 4 menunjukkan bahwa skor perlekatan pada kunjungan ke empat pada kedua kelompok terbukti berbeda secara signifikan. Ini menujukkan bahwa intervensi yang dilakukan oleh petugas kesehatan hanya berdasarkan pada buku modul yang sudah dirancang pada penelitian ini, dapat memperbaiki posisi dan perlekatan bayi pada ibu pada saat menyusu. Besarnya perbedan skor perlekatan pada kelompok eksperimen sebelum dan sesudah intervensi dapat terlihat pada tabel 4. Dimana skor perlekatan sebelum dan sesudah intervensi pada kelompok eksperimen juga berbeda secara signifikan. Dibandingkan dengan skor perlekatan pada kelompok kontrol yang tidak mengalami perubahan yang bermakna. Kondisi ini dapat dipengaruhi oleh pengalaman pertama ibu dalam menyusui anak (ibu primipara), ditambah dengan kurangnya support sistem.

Hasil penelitian ini juga menunjukkan pentingnya edukasi tentang posisi dan perlekatan saat menyusui dari petugas kesehatan terutama pada ibu-ibu primipara. Edukasi yang diberikan pun hendaknya komprehensif dan paripurna, disertai dengan kontrol dan pendampingan sehingga tujuan akhir dari anjuran pemberian ASI eksklusif dapat tercapai. Latch score yang baik dapat mendukung keberhasilan menyusui. Dengan perlekatan yang tepat ditambah posisi yang tepat, bayi dapat menghisap lebih optimal, sehingga asupan ASI dapat lebih optimal masuk ke tubuh bayi (Hockenberry \& Wilson, 
Oswati Hasanah, Riri Novayelinda, Dapatkah Program Home Visit Laktasi pada 4 Minggu Pertama meningkatkan Praktik Menyusui?

2009). Dengan asupan yang optimal, dapat terlihat adanya kenaikan berat badan yang signifikan. Berat badan bayi merupakan salah satu indikator pertumbuhan bayi. Hasil penelitian ini sejalan dengan riset yang dilakukan oleh Thakre, et all (2012) yang membuktikan bahwa informasi tentang pemberian posisi dan perlekatan yang di berikan pada minggu pertama terbukti memberikan pengaruh terhadap perbaikan posisi menyusui dan perlekatan bayi. Pada penelitian ini informasi dan pendampingan terus dilanjutkan hingga minggu ke empat.

Berdasarkan tabel 6 dan tabel 7, tidak terlihat ada perbedaan yang signifikan antara frekuensi dan durasi menyusui pada kelompok kontrol dan eksperimen pada kunjungan yang keempat dengna $\mathrm{p}$ value $=0,000(\mathrm{p}$ value $<\alpha)$. Tetap terlihat adanya peningkatan, walaupun peningkatannya tidak cukup bermakna. Ini menunjukkan edukasi yang efektif dapat meningkatkan pemahaman ibu tentang posisi dan perlekatan yang tepat. Berdasarkan penelitian Lestari, Amelia dan Rahmalia (2012), edukasi tentang laktasi yang dengan menggunakan media seperti dapat meningkatkan pengetahuan, kemampuan dan motivasi ibu tentang menyusui. Peningkatan frekuensi dan durasi menyusui akan berdampak posistif terhadap petumbuhan bayi di usia selanjutnya. Dengan frekuensi dan durasi yang cukup, asupan nutrisi dari ASI dapat diterima bayi lebih optimal.

\section{SIMPULAN}

Penelitian ini menunjukkan bahwa setelah 4 minggu pendampingan dan bimbingan, skor perlekatan pada bayi pada kelompok intervensi lebih tinggi dibandingkan dengan skor perlekatan pada kelompok kontrol, demikian juga dengan berat badan bayi pada kelompok eksperimen lebih tinggi dibandingkan dengan kelompok kontrol. Perbedaan skor perlekatan dan berat badan bayi pada minggu ke 4 pada kelompok terlihat signifikan.

\section{SARAN}

Penelitian ini merekomendasikan dilakukan penelitian lebih lanjut tentang pengaruh dari program ini terhadap praktik pemberian ASI hingga usia 4 bulan dan 6 bulan.

\section{DAFTAR PUSTAKA}

Badan penelitian dan pengembangan kesehatan kementrian kesehatan RI.(2013). Riset Kesehatan Dasar 2013. Jakarta. Diperoleh tanggal 1 Desember 2015 dari http://www.depkes.go.id/resources/down load/general/Hasil\%20Riskesdas\%20201 3.pdf

Dinkes Provinsi Riau. (2013). Profil kesehatan provinsi Riau 2012. Diperoleh tanggal 27 Januari $2016 \quad$ dari http://www.depkes.go.id/resources/down load/profil/PROFIL_KES_PROVINSI_2 012/04_Profil_Kes_Prov.Riau_2012.pdf

Kemenkes RI. (2014). Infodatin: Situasi dan analisis ASI eklsusif. Jakarta. Diperoleh 5 Desember 2015 dari http://www.depkes.go.id/resources/down load/pusdatin/infodatin/infodatin-asi.pdf 
Kronbrog, H \& Vaeth, M. (2009). How are effective breastfeeding technique and pacifier use related to breastfeeding problems and breastfeeding duration? Journal Compilation. Diperoleh tanggal $4 \quad$ Februari $2014 \quad$ dari http://www.googlescholar.com

Kumalasari, S., Sabrian, F. \& Hasanah, O. (2015). Faktor-faktor yang berhubungan dengan pemberian makanan pendamping ASI dini. Jurnal Online Mahasiswa Program Studi Ilmu Keperawatan Vol 2 No 1

Lestari, W., Amelia., N. R., \& Rahmalia, S. (2012). Efektifitas pendidikan kesehatan tentang ASI terhadap tingkat pengetahuan, kemampuan dan motivasi menyusui primipara. Jurnal Ners Indonesia dilihat dari http://ejournal. unri.ac.id/index.php/JNI/article/view/203 0/1995

Hockenberry, M. J. \& Wilson D. (2009). Wong's essentials of pediatric nursing, eighth edition. St Louis, Missouri: Mosby

I Mannan, dkk. (2008).Can early postpartum home visits by trained community health workers improve breastfeeding of newborn. Journal of Perinatology. Diperoleh tanggal 11 Januari 2014 dari http://www.ncbi.nlm.nih.gov/pubmed

Pertiwi, S.H., Solehati, T., \& Widiasih, R. (2012). Faktor - faktor yang mempengaruhi proses laktasi ibu dengan bayi usia 0-6 bulan di Desa Cibeusi Kecamatan Jatinangor. Student eJournals Vol 1 No 1 (2012). Diperoleh tanggal 3 Desember 2013 dari http://journals.unpad.ac.id/ejournal/articl e/view/697/743
Potts, N. L \& Mandleco, B. L. (2007). Pediatric nursing, caring for children and their families, second edition. New york: Thompson Delmar Learning.

Reeder, S. J., Martin, L., \& Griffin, D. K.(2011). Maternity nursing: family, newborn, and women's health care $\left(18^{\text {th }}\right.$ ed) (Yati Afiyanti dkk, Penerjemah). Jakarta: EGC

Susanti, R., Hasanah, O \& Utami, G. T. (2014) Perbandingan kenaikan berat badan BBLR yang diberi ASI dan susu formula pada dua minggu pertama perawatan. Jurnal Online Mahasiswa Program Studi Ilmu Keperawatan Vol 1 No 1. Diperoleh dari http://jom.unri.ac.id/ index.php/JOMPSIK/article/view/3474/3 370

Sabati, M. R. (2015). Peran petugas kesehatan terhadap keberhasilan pemberian ASI eksklusif (Studi Kualitatif Di Wilayah Puskesmas Sekaran Kecamatan Gunungpati Kota Semarang) dilihat dari http://eprints.undip.ac.id/47097/1/763 Maryasti_Rambu_Sabati.pdf

Thakre, S.B., Thakre, S.S., Ughade, S. M., Golawar, S., Thakre, A. D \& Priya, K. (2012). The Breastfeeding Practices: The Positioning and Attachment Initiative Among the Mothers of Rural Nagpur. Journal of Clinical \& Diagnostic Research, Vol. 6 Issue 7, p1215

WHO. (2014). Global nutrition targets 2025: breastfeeding policy breaf. Diunduh tanggal 5 Desember 2015 dari http://www.who.int/nutrition/publication s/globaltargets2025_policybrief_breastfe eding/en/ 